\title{
Grading, Hydrating, and Osmotically Priming Seed of Four Citrus Rootstock to Increase Germination Rate and Seedling Uniformity
}

Eric H.C. Chilembwe ${ }^{1}$

Fruit Crops Department, Institute of Food and Agricultural Sciences, University of Florida, Gainesville, FL 32611

William S. Castle Citrus Research and Education Center, Institute of Food and Agricultural Sciences, University of Florida, 700 Experiment Station Road, Lake Alfred, FL 33850

Daniel J. Cantliffe

Vegetable Crops Department, Institute of Food and Agricultural Sciences, University of Florida, Gainesville, FL 32611

Additional index words. polyethylene glycol, seed size, seed weight, shoot emergence, water soak, Citrus spp.

Abstract. Commercially processed citrus seeds of Carrizo citrange [Citrus sinensis (L.) Osb. $\times$ Poncirus trifoliata (L) Raf.], Swingle citrumelo (C. paradisi Macf. $\times P$. trifoliata), Cleopatra mandarin (C. reticulate Blanco), and sour orange ( $C$. aurantium L.) were used to test the effects of grading, hydrating, and priming on the rate of germination and seedling emergence. Sorting seed into groups by fresh weight or diameter did not generally improve seed performance. Seed fresh weight was highly correlated with maximum seed diameter; also, large seed weight and size were associated with a larger number of embryos. When seedlings from the extra embryos were removed, large seed produced the largest seedlings. Soaking seeds in aerated water significantly increased germination and emergence rates over unsoaked seeds. Soaking at $35 \mathrm{C}$ rather than $25 \mathrm{C}$ enhanced these differences. Priming seeds in one of three solutions of polyethylene glycol 6000 ( -0.6 to $-1.2 \mathrm{Mpa})$ was not successful $>$ as germination and emergence Per centages were lower than in distilled water.

Citrus rootstock are commonly propagated by seed, but because germination occurs slowly, often over a period of 60 days or more, seedling size in the nursery can be highly variable (Cohen, 1956; Fucik, 1978; Mobayen, 1980; Monselise, 1962; Platt and Optiz, 1973). This variation in plant size is undesirable. It complicates the timing of nursery operations and increases the amount of plant handling required, factors that increase production costs. Commercially, variation among citrus seedlings is usually reduced by size-grading the plants at the time of transplanting from the seedbed, which can involve discarding $50 \%$ of the plants.

Ideally, seed should germinate rapidly and give rise to uniform plants. Various treatments, such as water soaking (Chippendale, 1934; Elze, 1949; Kidd and West, 1918), osmotic priming (Guedes and Cantliffe, 1980; Heydecker, 1978; Heydecker and Gibbins, 1978; Khan et al., 1978), and grading (Carvalho et al., 1981; Hunter and Kannenberg, 1972; Lahiri et al., 1982) have improved the seed germination, plant uniformity, and yield of annual crops. One of the most effective techniques to improve citrus seed germination is to remove one or both seedcoats (Cohen, 1956; Monselise, 1959, 1962); however, this is not a common practice because it is generally too costly. Soaking citrus seed in water has had limited experimental and commercial success, probably because seed imbibition characteristics are not well known, particularly in relation to water temperature, aeration, and soak duration (Burns and Cog-

Received for publication 13 May 1991. Accepted for publication 13 Jan. 1992. Florida Agricultural Experiment Station Journal Series no. R-01576. The cost of publishing this paper was defrayed in part by the payment of page charges. Under postal regulations, this paper therefore must be hereby marked advertisement solely to indicate this fact.

'Present address: Bvumbe Agricultural Research Station, P.O. Box 5748, Limbe, Malawi. gins, 1969; Elze, 1949; Mobayen, 1980; Monselise, 1959). Seeds soaked in hormone solutions have given inconsistent results (Burns and Coggins, 1969; Castle, 1982).

Osmotic priming or grading of citrus seed has not been explored. The germination pattern of citrus seed has been studied in solutions of different water potential on filter paper (Mobayen and Milthorpe, 1978) and in soil (Kaufmann, 1969), but the seed were not removed from the osmoticum during the experiment. Grading seed before sowing has improved the performance of corn (Zea mays L.) (Hunter and Kannenberg, 1972) and pasture grasses (Lahiri et al., 1982). One preliminary study involving seeds of four citrus rootstock indicated that grading might be beneficial, but only germination percentages were reported (Castle, 1982). Grading is an otherwise unstudied method with citrus seed; moreover, citrus seed may respond differently to grading from other seeds because many are polyembryonic.

Our objective was to improve the germination rate and seedling uniformity of four common citrus rootstock by determining the potential benefits of soaking seed in water at one of two temperatures, osmotic priming, and grading seed by size or weight.

\section{Materials and Methods}

Seed sources. Seeds of four citrus rootstock, Carrizo citrange, Cleopatra mandarin, sour orange, and Swingle citrumelo, were obtained from commercial suppliers in Florida and California. The seeds had been extracted and handled by standard procedures including hot water and fungicide treatment (Plant and Opitz, 1973). The seeds were stored in polyethylene bags at $4 \mathrm{C}$ for $\approx 2$ to 4 months before use. Florida seeds were used in all experiments except where noted.

Laboratory germination. Seeds were germinated at $27 \mathrm{C}$ in an incubator with a 12-h light and dark period, using the standard 
rolled-paper-towel technique with intact seeds (Intl. Seed Testing Assn., 1976). Seeds were observed daily, and any newly germinated seeds (radicle protrusion) were noted and removed until no additional germination occurred for 10 days. The number of days to germination of the first and last seed (germination spread) was recorded. Percent germination and the mean number of days to germination (MDG) were calculated from the daily germination counts. The latter was used as an index of germination rate and was calculated following Gerson and Honma (1978):

$$
M D G=\frac{\Sigma \mathrm{N}_{\mathrm{i}} \mathrm{T}_{\mathrm{i}}}{\Sigma \mathrm{N}_{\mathrm{i}}}
$$

where $\mathrm{N}_{\mathrm{i}}$ is the number of seed germinated at time $\mathrm{T}_{\mathrm{i}}$.

Emergence studies. A heated fiberglass greenhouse was used to study seedling emergence. Daily air maxima and minima, averaged weekly, ranged from $\approx 25$ to $30 \mathrm{C}$ and 15 to $20 \mathrm{C}$, respectively. The emergence container was the Speedling tray with 128 pyramidal-shaped cells, each $4 \mathrm{~cm}^{2}$ at the top and 12 $\mathrm{cm}$ deep. The trays were filled with a commercial medium consisting of 3 peat :1 perlite $: 1$ vermiculite (by volume) amended with $\mathrm{P}$ and micronutrients and limed to $\mathrm{pH} 6.0$ (Castle et al., 1979). Each cell of the tray was sown with one intact seed laid horizontally and covered with $0.5 \mathrm{~cm}$ coarse vermiculite. A solution of $20 \mathrm{~N}-0.8 \mathrm{P}-1.6 \mathrm{~K}$ fertilizer was applied weekly, and the trays were watered once or twice weekly, as needed. Trays were checked daily, and any newly emerged shoots were recorded. When more than one seedling per cell emerged, the number of plants per seed was recorded, and then seedlings were thinned to leave the most vigorous one. The same data were recorded and calculated as described for the incubator tests. Plant dry weight and height were determined at the end of each experiment.

Grading by seed fresh weight. Samples of 500 seeds were drawn from batches of 15,000 to 30,000 seeds of each rootstock and source. Seed fresh weights were measured and standard statistical parameters calculated. As seed fresh weights appeared to be normally distributed, a second 600-seed sample was drawn for each rootstock from the Florida sources. The seeds were weighed, arranged in order of increasing weight, then divided into five classes of 120 seeds each so that each class was $20 \%$ of the seed weight range. The classes were labeled as extra small to extra large. The five classes plus ungraded seed constituted the treatments for an emergence study. Seeds were sown separately by rootstock in randomized complete blocks with 20seed plots and six replications. The experiments were terminated 5 months later.

Grading by seed diameter. The diameter, at the widest point along the micropylar-chalazal axis, and fresh weight of 80 intact seeds were measured for each rootstock, and a correlation coefficient was calculated. Seeds of each rootstock were also separated into three size classes by screening and labeled as small, medium, and large. These three size classes plus an ungraded lot for each rootstock were the treatments for germination tests (three 50-seed replications) and separate emergence experiments (32-seed plots, four replications in randomized complete blocks) that were terminated $\approx 4$ months after sowing the seeds.

Seed hydration, soak temperature, and osmotic priming. The time course of imbibition and associated changes in fresh weight were determined for seeds soaked in distilled water or aqueous solutions of polyethylene glycol (PEG) 6000. Solutions of -0.6 , -0.9 , or $-1.2 \mathrm{MPa}$ osmotic potential at $30 \mathrm{C}$ were prepared by mixing, respectively, 23.5\%, 29.1\%, and 34\% (w/v) PEG
6000 in water (Michel and Kaufmann, 1973). A 10-g unsorted, intact seed sample of each rootstock was imbibed in each of these aerated solutions or in water. The seeds were periodically removed, rinsed in water, blotted to remove excess water, weighed, and returned. Measurements were continued for each rootstock until the first seed germinated in water. Initial and final seed water contents were determined on a dry-weight basis (Intl. Seed Testing Assn., 1976).

A soak duration that did not appear to reduce seed viability was selected for each rootstock from the respective imbibition curves for seed soaked in water. These durations and two temperatures were the basis for separate water soak germination and emergence trials for each rootstock. Unsorted, intact seeds of each rootstock were soaked in $25 \mathrm{C}$ aerated water for 7 days while at $35 \mathrm{C}$, sour orange and Cleopatra mandarin seeds were soaked for 5 days, and Carrizo citrange and Swingle citrumelo seeds for 2 days. The germination tests involved three 50 -seed replicates per rootstock; the emergence trials involved 20-seed plots and six replications in randomized complete blocks; these trials were terminated after 90 days. All trials included a sample of unsoaked seeds. Additional seeds of the four rootstock were osmotically primed at $25 \mathrm{C}$ in $-0.6,-0.9$, or $-1.2 \mathrm{MPa}$ solutions prepared as described previously. The seeds were immersed in 1.8-liter aerated solutions at $25 \mathrm{C}$ for 7,14 , or 21 days. Immediately after priming, 150 seeds of each rootstock and an equal number of unsoaked seeds were divided into three replicates and germinated. Carrizo citrange and sour orange seedling emergence were studied in a split-plot design with four replications of 32-seed plots. Priming duration was the main plot and solution osmotic potential the subplot. The emergence experiments did not include the 14-day treatment and were concluded $\approx 90$ days after sowing.

Statistical analysis. Rootstock were considered separately in each experiment. Data were evaluated by analysis of variance or regression procedures with the unsorted seed treatment excluded from the latter. Percentage data were arcsin-transformed, and seedling height data were log-transformed before analysis. The seed diameter and weight classes were assigned the arbitrary values of 1 to 3 or 5 , respectively, for the regression analyses.

\section{Results}

Seed grading. Seed fresh weights were normally distributed with differences among rootstock in the mean values and the range (Table 1; Fig. 1). California seeds mostly had smaller mean fresh weights than Florida seeds (Table 1).

Seed fresh weight was positively correlated with seed diameter $\left(r^{2}=0.95\right.$; pooled data) and increased according to the following significant $(P<0.05)$ linear regression equations where seed fresh weight is the dependent variable: Carrizo citrange, $\mathrm{Y}=-189.0+64.0 \mathrm{x}$ Cleopatra mandarin, $\mathrm{Y}=-61.4+$ $30.7 \mathrm{x}$; sour orange, $\mathrm{Y}=-89.6+39.2 \mathrm{x}$; and Swingle citrumelo, $\mathrm{Y}=-263.7+70.3 \mathrm{x}$.

Grading seeds by fresh weight or diameter (size) had no significant effect on germination rate, regardless of rootstock, as compared with ungraded seeds (data not given). Final germination was $>90 \%$ in all instances. Germination began within 5 to 10 days and continued for 20 to 30 days. However, seedling emergence and growth were affected when seeds were sorted by fresh weight or size as typified by Carrizo citrange (Table 2; diameter data not given). Seedling emergence increased linearly or quadratically $(P<0.05)$ as seed weight or size increased. Ungraded seed performance generally did not differ by 
Table 1. Variation in citrus seed fresh weight as influenced by rootstock and seed source. ${ }^{2}$

\begin{tabular}{lcccc}
\hline \hline & & \multicolumn{3}{c}{ Parameter } \\
\cline { 3 - 5 } Rootstock & $\begin{array}{c}\text { Seed } \\
\text { sourcey }^{y}\end{array}$ & $\begin{array}{c}\text { Mean } \\
(\mathrm{mg})\end{array}$ & $\begin{array}{c}\text { CV } \\
(\%)\end{array}$ & $\begin{array}{c}\text { Mode } \\
(\mathrm{mg})\end{array}$ \\
\hline Carrizo citrange & FL & 261 & 25 & $220-240$ \\
& CA & 228 & 25 & $210-230$ \\
Cleopatra mandarin & FL & 82 & 21 & $70-90$ \\
Sour orange & CA & 88 & 28 & $80-100$ \\
& FL & 147 & 20 & $140-160$ \\
Swingle citrumelo & CA & 120 & 28 & $120-140$ \\
& FL & 216 & 27 & $230-250$ \\
& CA & 179 & 28 & $200-220$ \\
\hline
\end{tabular}

${ }^{2}$ Data obtained from a 500 -seed sample for each rootstock and source. Fresh weights were divided into 20 -mg intervals for frequency distributions and parameter calculations.

${ }^{y} \mathrm{FL}=$ Florida; $\mathrm{CA}=$ California .

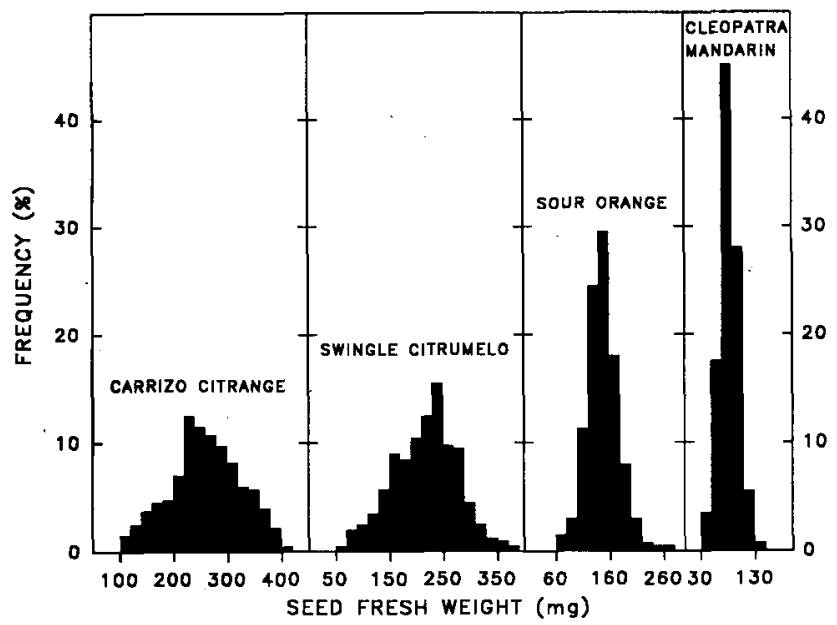

Fig.1. Fresh-weight distibutions in 20-mg increments for 500 intact Florida-grown seed of each citrus rootstock.

$\mu$ opethan $\approx 10 \%$ from that of seeds in the large or small classes. The emergence percentages were generally $>80 \%$ for all rootstocks. Seed weight or size did not affect mean days to emergence, emergence of the first seed, or emergence spread in most instances.

The percentages of seeds from which more than one seedling emerged increased as seed fresh weight or size increased. The data were generally best described by a quartic equation $(P<$ $0.05)$ but, with each rootstock, the major component of the total variation was linear. There was a significant $(P<0.05)$ linear relationship for each rootstock between seedling growth (dry weight and height) and seed fresh weight (Carrizo citrange, Table 2) and size (data not given).

Seed hydration, soak temperature, and osmotic priming. Seeds of the four rootstock initially contained $\approx 50 \%$ water on a dryweight basis and $>90 \%$ at the end of the imbibition period. Water uptake was substantially greater during the first $18 \mathrm{~h}$ than during the following $240 \mathrm{~h}$ (Fig. 2A). Changes in seed fresh weight depended on initial seed water content. Seeds of those rootstock with the higher water contents, such as Carrizo citrange, had the smallest fresh-weight gains and were the first to germinate during the imbibition period (Fig. 2A).

The germination percentages for seeds of each rootstock were $>90 \%$ and were not affected by soaking or soak temperature; however, soaked seeds germinated sooner and faster than unsoaked ones, and this difference was increased at the higher soak temperature (Table 3). Unsoaked seeds began to germinate within 5 to 10 days and soaked seeds within 2 to 5 days, but soaked and unsoaked seeds had similar time periods to germination completion (data not given). Results of the emergence experiments were virtually identical to those of the germination trials (Table 3). After 3 months, Carrizo citrange seedlings from seeds soaked at $35 \mathrm{C}$ had a larger mean dry weight than those from seeds that were not soaked or were soaked at $25 \mathrm{C}$. A similar trend occurred among the sour orange seedlings, but the differences were not significant.

The rates of water uptake and seed fresh weight increases were directly related to the solution osmotic potential (Fig. 2B). Carrizo citrange seeds imbibed at the highest rate in distilled water and at the lowest rate in the - 1.2 MPa solution. The seeds soaked in distilled water had a final water content of $98 \%$ (Fig. 2A), and those in the $-0.6,-0.9$, and -1.2 MPa solutions contained $88 \%, 83 \%$, and $78 \%$ water, respectively, after $258 \mathrm{~h}$. Similar results were obtained with seeds of other rootstock.

In the seed priming experiments, there were no interactions between soak duration and solution osmotic potential; thus, main effects are reported. There were also no meaningful differences among rootstock in their responses to the treatments. Germination and seedling emergence percentages were $\approx 75 \%$ for the 7-day soak but $>90 \%$ for the longer durations and were also reduced by the solutions regardless of their osmotic potential as compared to the unprimed seed (data not given). The largest difference was between seeds primed for 7 days and their unprimed control; at the longer soak durations, this difference was less pronounced and usually not significant. Solution osmotic potential and soak duration accelerated germination and seedling emergence, but the difference in the mean response between primed and unprimed seed was generally $<4$ days.

\section{Discussion}

Our objective was to increase the rate of germination and seedling emergence to increase plant uniformity and the efficiency of citrus nursery operations. The treatments in our study were based on seed physical traits and physiological activity. None of the treatments had a large effect on the responses measured. Furthermore, seed and seedling behavior were generally independent of rootstock.

Poor seed quality or viability did not appear to be a factor in our experiments. Germination and emergence values were $>85 \%$, as consistently reported for citrus seeds in other experiments (Button et al., 1971; Camp et al., 1933; Castle, 1982; Cohen, 1956; Elze, 1949). Values < $80 \%$ would be indicative of poor seed quality and/or unfavorable growing conditions (Chacko and Singh, 1968; Cohen, 1956; Monselise, 1953). The germination and emergence patterns were typical for citrus seed, i.e., the first seedling emerged in $\approx 15$ days and the last one $\gg 30$ days later for a total emergence period of 45 to 90 days (Button et al., 1971; Castle, 1982; Monselise, 1962). Germination under the more favorable and uniform incubator conditions was faster than the rate of seedling emergence in a greenhouse with diurnal temperature fluctuations; but treatment effects were similar. Overall, the typical pattern was unrelated to rootstock except that Swingle citrumelo seeds generally emerged first and most rapidly, followed by Carrizo citrange, sour orange, and Cleopatra mandarin.

The benefit of grading citrus seed is questionable. The results 
Table 2. Seedling emergence and growth under greenhouse conditions of Carrizo citrange seed graded by fresh weight. ${ }^{z}$

\begin{tabular}{|c|c|c|c|c|c|c|}
\hline \multirow[b]{2}{*}{$\begin{array}{l}\text { Emergence and } \\
\text { growth variable }\end{array}$} & \multicolumn{6}{|c|}{ Seed fresh wt class } \\
\hline & $\begin{array}{l}\text { Extra } \\
\text { small } \\
\end{array}$ & Small & Medium & Large & $\begin{array}{l}\text { Extra } \\
\text { large }\end{array}$ & Unsorted \\
\hline Emergence $(\%)$ & 87. & 89 & 97 & 96 & 91 & 93 \\
\hline $\begin{array}{l}\text { Mean time to emergence } \\
\text { (days) }\end{array}$ & 26.0 & 28.4 & 26.4 & 26.1 & 25.9 & 27.4 \\
\hline $\begin{array}{l}\text { Emergence of first } \\
\text { seedling (days) }\end{array}$ & 15.5 & 15.3 & 15.0 & 13.7 & 14.0 & 16.0 \\
\hline Emergence spready (days) & 28.2 & 30.8 & 29.3 & 28.5 & 31.2 & 27.7 \\
\hline Polyembryony $(\%)$ & 26 & 48 & 47 & 51 & 63 & 54 \\
\hline Mean seedling dry wt (mg) & 557 & 597 & 630 & 663 & 680 & 517 \\
\hline Mean seedling ht $(\mathrm{cm})$ & 10.1 & 10.9 & 10.6 & 11.6 & 11.4 & 10.2 \\
\hline
\end{tabular}

${ }^{2}$ Data were obtained from six replicates of 20 -seed plots, where each treatment (class) represents $20 \%$ of the range in fresh weight of a 600 -seed sample. Significant $(\mathrm{P}<$ $0.05)$ regression equations; $x=$ seed weight class: Percent emergence $=0.936+$ $0.267 \mathrm{x}-0.038 \mathrm{x}^{2}, \mathrm{r}^{2}=0.29$; percent polyembryony $=-0.566+1.818 \mathrm{x}-0.886$ $\mathrm{x}^{2}+0.181 \mathrm{x}^{3}-0.013 \mathrm{x}^{4}, r=0.91$; seedling dry weight $=531.633+31.4 \mathrm{x}, r^{2}$ $=0.80 ; \log$ seedling height $=2.302+0.027 \mathrm{x}, r^{2}=0.16$. Regression analyses did not include the unsorted seed treatment. Mean time to emergence, emergence of first seedling, and emergence spread were not significantly related to seed fresh weight.

${ }^{y}$ Number of days between the emergence of the first and last seedlings.

${ }^{x}$ Percentage of germinated seed with more than one seedling per seed.

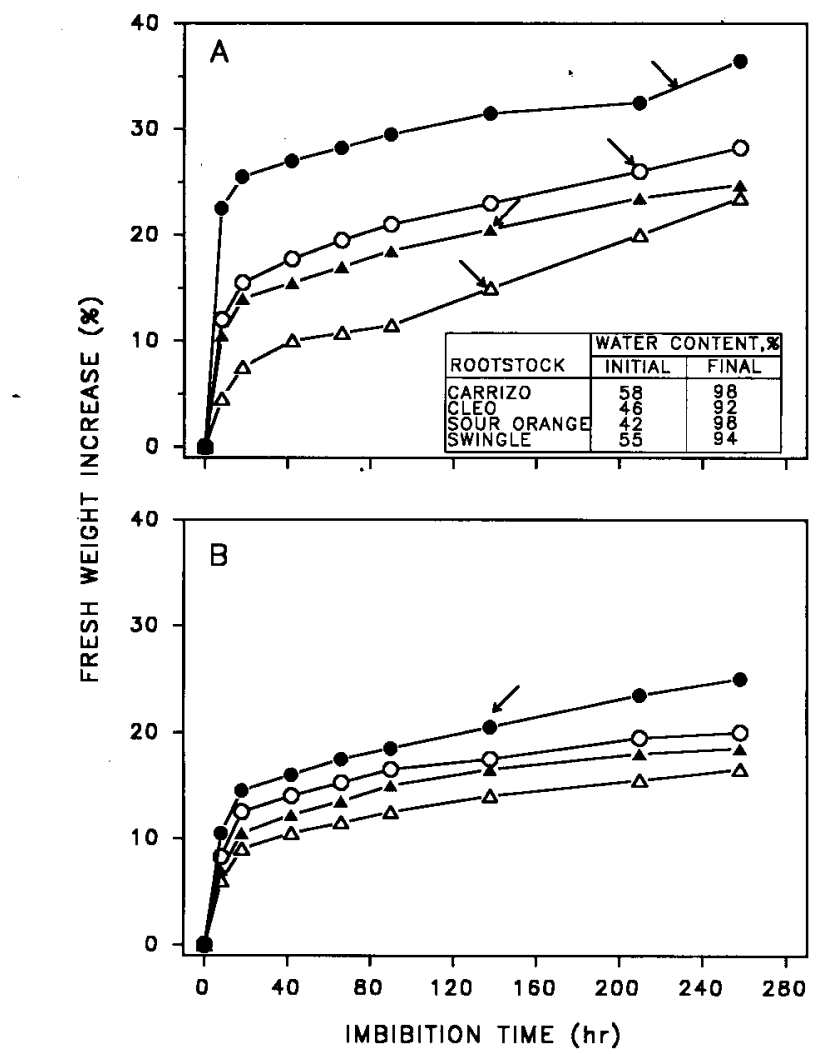

Fig. 2. Fresh-weight changes in $10-\mathrm{g}$ samples of unsorted, intact (A) sour orange $(\mathbf{O})$, Cleopatra mandarin $(\mathrm{O})$, Carrizo citrange $(\boldsymbol{A})$, and Swingle citrumelo $(\triangle)$, seeds imbibed at $30 \mathrm{C}$ in aerated water. Initial and final water contents are on a dry-weight basis; (B) Carrizo citrange seeds imbibed at $30 \mathrm{C}$ in aerated distilled water $(\mathcal{O})$ or -0.6 $(\mathrm{O}),-0.9(\boldsymbol{\Delta})$, or $-1.2 \mathrm{MPa}(\triangle)$ PEG solutions. Arrows mark the time when the first seed germinated.

clearly show that the variation in seed fresh weight and size was only weakly related to seed germination behavior. Isolating a
Table 3. Germination and seedling emergence and growth after soaking citrus seeds in aerated water at two temperatures.'

\begin{tabular}{|c|c|c|c|c|}
\hline \multirow{2}{*}{$\begin{array}{c}\text { Temp of } \\
\text { soak water } \\
\left({ }^{\circ} \mathrm{C}\right)\end{array}$} & \multicolumn{4}{|c|}{ Rootstock } \\
\hline & $\begin{array}{l}\text { Carrizo } \\
\text { citrange }\end{array}$ & $\begin{array}{l}\text { Cleopatra } \\
\text { mandarin }\end{array}$ & $\begin{array}{l}\text { Sour } \\
\text { orange }\end{array}$ & $\begin{array}{c}\text { Swingle } \\
\text { citrumelo }\end{array}$ \\
\hline & \multicolumn{4}{|c|}{ Mean time to germination (days) } \\
\hline $\begin{array}{l}\text { Not soaked } \\
25 \\
35\end{array}$ & $\begin{array}{l}21.9 \mathrm{a}^{\mathrm{y}} \\
19.3 \mathrm{~b} \\
11.5 . \mathrm{c}\end{array}$ & $\begin{array}{r}16.7 \mathrm{a} \\
12.9 \mathrm{~b} \\
9.5 \mathrm{c}\end{array}$ & $\begin{array}{r}16.0 \mathrm{a} \\
12.0 \mathrm{~b} \\
9.6 \mathrm{c}\end{array}$ & $\begin{array}{r}10.2 \mathrm{a} \\
4.2 \mathrm{~b} \\
5.0 \mathrm{~b}\end{array}$ \\
\hline 35 & \multicolumn{4}{|c|}{ Mean time to emergence (days) } \\
\hline $\begin{array}{l}\text { Not soaked } \\
25 \\
35\end{array}$ & $\begin{array}{l}35.6 \mathrm{a} \\
32.9 \mathrm{ab} \\
29.3 \mathrm{~b}\end{array}$ & $\begin{array}{l}--- \\
---\end{array}$ & $\begin{array}{l}40.9 \mathrm{a} \\
34.1 \mathrm{~b} \\
29.0 \mathrm{c}\end{array}$ & -- \\
\hline 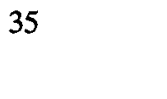 & \multicolumn{4}{|c|}{ Mean seedling dry wt (mg) } \\
\hline $\begin{array}{l}\text { Not soaked } \\
25 \\
35\end{array}$ & $\begin{array}{l}245 \mathrm{~b} \\
256 \mathrm{~b} \\
340 \mathrm{a}\end{array}$ & $\begin{array}{l}--- \\
--- \\
--\end{array}$ & $\begin{array}{l}306^{\mathrm{Ns}} \\
315 \\
322\end{array}$ & $\begin{array}{l}--- \\
---\end{array}$ \\
\hline
\end{tabular}

${ }^{2}$ The soak duration at $25 \mathrm{C}$ was 7 days for seeds of the four rootstock, and at $35 \mathrm{C}$, it was 2 days for Carrizo and Swingle seeds and 5 days for Cleopatra and sour orange seeds. The latter two rootstock were not included in the emergence tests.

${ }^{y}$ Mean separation in columns within each variable and rootstock by Duncan's multiple range test, $P=0.05$.

portion of the variation by sorting seed into weight and size classes had little effect on the rate and pattern of germination and seedling emergence; also, the results were similar when relatively uniform seed such as those of Cleopatra mandarin were compared with those of Carrizo citrange, which had a much greater range in seed size.

Some differences in germination and emergence rate were observed between the extremes in seed fresh weight and size but were too small to justify grading to remove large and small seed. Seeds in those two classes represented only a small part of the population. Nevertheless, some grading might be useful 
to eliminate the lower $20 \%$, because those seeds often had relatively low emergence percentages. The smaller seeds also tended to produce seedlings smaller than those from large seed, which is consistent with evidence from other crops relating seed size to seedling growth rate (Carvalho et al., 1981; Dure, 1975; Hunter and Kannenberg, 1972). However, the biggest citrus seeds in our experiments were larger and heavier because extra embryos were present. We removed the extra seedlings in our tests; if they had not been removed, as is the usual commercial practice, then the smaller and larger seeds might have produced more similarly sized seedlings.

The only treatment that produced results of possible practical consequence was a heated water soak. Water soaking accelerated germination and emergence rates over the rates of the unsoaked seed by $25 \%$ to $50 \%$ at the high temperature $(35 \mathrm{C})$ without any effect on percent germination or emergence. The probable advantage of soaking seed is the time gained from imbibition and initiation of germination before sowing. In addition, environmental conditions for field- or greenhouse-sown seed often fluctuate and are less than optimum, thereby prolonging the imbibition period and seedling emergence (Mayer and Shain, 1974). Softening of the seedcoats and leaching of inhibitors may also have contributed to the advantage obtained from water soaking (Mumford and Panggabean, 1982).

The warmer water soak was superior to the cooler one, but it appeared that nontreatment temperature effects were greater. Carrizo seedlings began to emerge $\approx 15$ days sooner when seed were sown in September than in December when diurnal air, and probably soil, temperatures were lower. Earlier work also indicated that germination and emergence rates were accelerated as temperature increased (Camp et al., 1933; Fawcett, 1929; Mobayen, 1980; Monselise, 1959).

Seed priming is an effective means of improving germination and plant uniformity (Heydecker and Gibbins, 1978), but our data were variable and inconclusive with citrus seeds. Primed seeds germinated and emerged slightly faster than unprimed ones; partly as a result of the imbibition advantage gained from soaking, as previously explained, but at the cost of reduced germination and emergence percentages. Aeration may have become a limiting factor during the relatively long soak durations and at the higher PEG concentrations (Come and Tissaoui, 1972); also, PEG may have damaged the seed directly (Kaufmann, 1969; Mobayen and Milthorpe, 1978). We only tested one osmoticum; others should be studied.

Our results demonstrated that the performance of citrus seeds was not strongly related to physical traits and other treatments that apparently did not greatly alter basic germination and initial growth processes. Nevertheless, several of the treatments we studied provided some benefit individually, suggesting a meaningful advantage to commercial nurserymen by combining seed soaking in water at 35C with sowing seeds horizontally (Chilembwe et al., 1988) and removing the smallest $20 \%$ of the seeds to increase seedling size and uniformity.

\section{Literature Cited}

Bums, R.M. and C.W. Coggins, Jr. 1969. Sweet orange germination and growth aided by water and gibberellin seed soak. Calif. Agr. 23(12):18-19.

Button, J., C.H. Bomman, and B.A. Hackland. 1971. Effect of some presowing treatments on the germination of Poncirus trifoliata and Troyer citrange seeds. Citrus and Subtropical Fruit J. 45(1):9-11.
Camp, A. F., H. Mowry, and K.W. Loucks. 1933. The effect of soil temperature on the germination of citrus seeds. Amer. J. Bet. 20:348-357.

Carvalho, N. M., L.M. Massoni Filho, and R. Sadder. 1981. Effect of peanut (Arachis hypogea) seed size and position in the soil on total and speed of emergence. Seed Sci. Technol. 9:849-852.

Castle, W.S. 1982, A review of citrus seed biology and its relationship to nursery practices. 1981 Proc. Intl. Soc. Citriculture 1: 113-119.

Castle, W. S., W.G. Adama, and R.L. Dilley. 1979. An indoor container system for producing citrus nursery trees in one year from seed. Proc. Fla. State Hort. Soc. 92:3-7.

Chacko, E. and R.N. Singh. 1968. Studies on the germination and longevity of fruit-tree seeds - citrus spp. Indian J. Hort. 25:94-103.

Chilembwe, E. H. C., W.S. Castle, D. Cantliffe, and W.J. Wiltbank. 1988. Reduction in seedling size variability of four citrus rootstock by seed orientation. Acts Hort. 218:91-94.

Chippendale, H.G. 1934. The effect of soaking in water on the seeds of some graminae. Ann. BioL XXI:225-232.

Cohen, A. 1956. Studies on the viability of citrus seeds and certain properties of their coats. Israel J. Bet. 5:200-209.

Come, D. and T. Tissaoui. 1972. Interrelated effects of imbibition, temperature and oxygen on seed germination, p. 157-168. In W. Heydecker (cd.). Seed ecology. The Pennsylvania State Univ. Press, University Park.

Dure, L. 1975. Seed formation. Annu. Rev. Plant Physiol. 26:259-278.

Elze, D.L. 1949. Germination of citrus seeds in relation to certain nursery practices. Palestine J. Bet. 7:69-80.

Fawcett, H.E. 1929. Temperature experiments in germinating orange seeds Calif. Citrograph 14(12):515.

Fucik, J.E. 1978. Sources of variability in sour orange seed germination and seedling growth. 1977 Proc. Intl. Soc. Citriculture 1:141-143.

Gerson, R. and S. Honma. 1978. Emergence response of the pepper at low soil temperature. Euphytica 27:151-156.

Guedes, A.C. and D.J. Cantliffe. 1980. Germination of lettuce seeds at high temperature after seed priming. J. Amer. Soc. Hort. Sci. 105(6):777-781.

Heydecker, W. 1978. 'Primed' seeds for better crop establishments. Span 21(1):12-14.

Heydecker, W. and B.M. Gibbins. 1978. The priming of seeds. Acts Hort. $83: 213-223$

Hunter, R.B. and L.W. Kannenberg. 1972. Effects of seed size on emergence, grain yield and plant height in corn. can. J. Plant Sci. 52:252-256.

International Seed Testing Association. 1976. International rules for seed testing. Seed Sci. Technol. 4: 1-177.

Kaufmann, M.R. 1969. Effects of water potential on germination of lettuce, sunflower and citrus seeds. Can. J. Bet. 47:1761-1764.

Khan, A.A., J.S. Kar-Ling Tao, B. Borkowska Knypl, and L.E. Powell. 1978. Osmotic conditioning of seeds: Physiological and biochemical changes. Acts Hort. 83:267-277.

Kidd, F. and C. West. 1918. Physiological predetermination: The influence of the physiological condition of the seed upon the course of subsequent growth and upon yield. The effects of soaking seeds in water. Ann. Applied Biol. $5: 1-10$.

Lahiri, A. N., S. Kathju, and K.A. Shankamarayan. 1982. Comparative performance of Cenchrus ciliaris pastures raised from large and small seeds. Seed Sci. Technol. 10:207-213.

Mayer, A.M. and Y. Shain. 1974. Control of seed germination. Annu. Rev. Plant Physiol. 25:167-193.

Michel, B.E. and M.R. Kaufmann, 1973. The osmotic potential of polyethylene glycol 6000. Plant Physiol. 51:914-916.

Mobayen, R.G. 1980. Germination and emergence of citrus and tomato seeds in relation to temperature. J. Hort. Sci. 55:291-297.

Mobayen, R.G. and F.L. Milthorpe. 1978. Citrus seed germination as influenced by water potential and salinity. 1978 Proc. Intl. Soc. Citriculture 1:247249

Monselise, S.P. 1953. Viability tests with citrus seeds. Palestine J. Bet. VIII:152157.

Monselise, S.P. 1959. Citrus germination and emergence as influenced by temperature and seed treatments. Israel J. Bet. 7:29-34.

Monselise, S.P. 1962. Citrus aced biology. Proc. 16th Intl. Hort. Congr. 5:559565

Mumford, P.M. and G. Panggabean. 1982. A comparison of the effects of dry storage on seeds of Citrus species. Seed Sci. Technol. 10:257-266.

Platt, R.G. and K.W. Opitz. 1974. Propagation of citrus, p. 1-47. In: W. Reuther (cd.). The citrus industry, vol. 3. Univ. Calif. Agr. Press, Berkeley. 